\title{
Liberation or Anarchy? The Janus Nature of Groundwater Use on North Africa's New Irrigation Frontiers
}

\author{
Marcel Kuper, Nicolas Faysse, Ali Hammani, Tarik Hartani, \\ Serge Marlet, Meriem Farah Hamamouche, and Fatah Ameur
}

\begin{abstract}
Two contrasting views prevail on groundwater use in situations of predominantly state-led irrigation development. The first considers 'groundwater as liberation', i.e., how, by capturing the irrigation initiative, farmers liberated themselves from 'state' water, enabling more intensive and productive agriculture. The second view - 'groundwater as anarchy' - considers groundwater as a
\end{abstract}

M. Kuper $(\triangle)$

Cirad, Umr G-Eau, Montpellier, France

IAV Hassan II, Rabat, Morocco

e-mail: Marcel.kuper@cirad.fr

N. Faysse

Cirad, Umr G-Eau, Montpellier, France

National Agronomy School (ENA), Meknes, Morocco

A. Hammani

IAV Hassan II, Rabat, Morocco

T. Hartani

ENSA, El Harrach, Algeria

S. Marlet

Cirad, Umr G-Eau, Montpellier, France

National Research Institute in Rural Engineering, Water Management and Forestry (INRGREF), Tunis, Tunisia

M.F. Hamamouche • F. Ameur

Cirad, Umr G-Eau, Montpellier, France

IAV Hassan II, Rabat, Morocco

ENSA, El Harrach, Algeria 
declining resource, overexploited by millions of individualistic farmers in the absence of effective groundwater governance with mounting inequalities in groundwater use. We analyse the Janus nature of groundwater in the expanding groundwater economy in Morocco, Algeria and Tunisia. Groundwater has redesigned irrigation frontiers, and caters to over $60 \%$ of the total irrigated area, supplying more than 500,000 farms with irrigation water. However, more than half of the aquifers are overexploited, and typically only 40-50\% of farmers in a given area access groundwater. We conclude that groundwater use in North Africa cannot be qualified as anarchy, but rather as a negotiated disorder where the interests of farmers, the private sector, and the state, are continuously realigned. Groundwater 'liberated' farmers only partially from 'state' water, as the state has remained present in groundwater economies. Moreover, groundwater concerned a minority of farmers, who are often keen to get state support when facing resource depletion or harsh agricultural markets. Breaking the current conundrum will require creating space for change, by making visible the current and future effects of groundwater dynamics to local actors, and supporting the building of coalitions of actors towards a sustainable agricultural use of groundwater.

\subsection{Introduction: Private Groundwater Use in a Context of State-Led Irrigation Development}

The development of irrigation in North Africa in the twentieth century was long associated with state-implemented large-scale surface irrigation schemes. This masked the less visible but continuously increasing exploration and development of groundwater resources (Swearingen 1987; Côte 2002; Mamou and Kassah 2002). The increase in the use of groundwater probably remained more or less unseen from the State's point of view - because groundwater was used by private settlers or communities, "without order or specific plan" (Chevalier 1950). The rapid and massive development of groundwater use, especially since the 1980s, has changed this viewpoint. Today, groundwater is delivered through hundreds of thousands of mostly private (tube-) wells to more than 500,000 farm holdings in Algeria, Morocco and Tunisia, irrigating more than 1.75 million ha, and opening up new irrigation frontiers every day.

Two contrasting views prevail in the literature on the emergence of a groundwater economy, especially in countries with predominantly State-led irrigation development (Shah 2009). The first considers 'groundwater as liberation', i.e., how, by recapturing the irrigation initiative, farmers 'liberated' themselves from State water, and consequently from increasingly inadequate irrigation services, compulsory cropping patterns, and more generally from the "implacable order of an extraordinary authority that is at the origin of the distribution of life" (Pascon 1978). According to this view, private groundwater use enabled more intensive and 
productive agriculture. Siebert et al. (2010) estimated that 113 out of 300 million ha in the world are currently irrigated with groundwater. Groundwater-based systems generate annual revenues of \$210-230 billion (Lopez-Gunn and Llamas 2008; Shah 2009), and are economically three to ten times more efficient than surface water systems (Llamas and Martinez-Santos 2005). Groundwater also provides social status, as farmers who are part of the groundwater economy qualify themselves as 'modern' (Quarouch et al. 2014). Finally, groundwater has a pro-poor aura as it has enabled the survival of many small-scale farms with insufficient access to surface irrigation (Penov 2004; Kuper et al. 2012).

The second view - 'groundwater as anarchy' - considers groundwater as a declining resource, overexploited by millions of individualistic farmers in the absence of effective groundwater governance (Shah 2009). More than $10 \%$ of the world's food production depends on aquifers that are overexploited and threatened (Postel 1999). In addition, inequalities in groundwater access, often building on the individual's position in society, were shown to contribute to marginalization of certain categories of farmers and to favour social differentiation (Prakash 2005; Amichi et al. 2012). According to this view, the growing anarchy in the exploitation of groundwater for irrigation is due to 'inherent' features of the groundwater economy, i.e. the rapid development of mostly 'illicit' tube-wells at the initiative of private farmers, the diffuse and relatively cheap access to groundwater through individual pumps, limited scientific knowledge and data, and the political weight of groundwater users (Allan 2007; Moench 2007; Shah 2009). Such features make conventional management responses to groundwater overexploitation, including administrative regulation, economic instruments, water markets, community management, generally at best a theoretical exercise far from reality in the field (Moench 2007). In India for example, such "policy measures. . . have all been discussed ad nauseum. . . as the groundwater situation is turning from bad to worse" (Shah et al. 2003).

Both views acknowledge the weaknesses of the state in controlling the dynamics of groundwater economies; the first one praises this situation, while the second one laments it. They describe the state as the main absentee of these new dynamics. But is this really the case in Algeria, Morocco and Tunisia, where the state had such a prominent role in earlier surface irrigation development? In this chapter, we want to explore the dynamics of groundwater economies: their growth and the new irrigation frontiers they set, what takes place at farm level, and the imminent risks at farm and aquifer level. This will help us reconsider whether the state is as absent as it seems at first sight, and whether it should remain so. To do so, we acknowledge the Janus nature of groundwater, as both an "enabler of important rural socio-economic transition", but which is exploited by "short-term water-using practices" and presided over by passive political economies (Allan 2007). We provide a brief history of the emergence and size of the groundwater economy at national level, and we analyse the pathways of some contrasting local groundwater economies in order to engage the debate on current groundwater use practices, the actors involved (and those who are excluded). 


\subsection{The Emergence of the Groundwater Economy}

\subsubsection{Groundwater Use Was Long Masked by Large-Scale Irrigation Development (1920-1980)}

Algeria, Morocco and Tunisia have a long-standing tradition of using groundwater for irrigated agriculture. Communities created and managed irrigation systems, including groundwater-based systems such as the foggara or khettara systems, which are "subterranean aqueducts engineered to collect groundwater and channel it to surface canals" (Lightfoot 1996), but also through artesian wells and springs. In the twentieth century, surface and groundwater resources were progressively placed in the public domain, thereby limiting traditional water rights in time and in space, and liberating water resources for "State water" (Pascon 1978; Riaux 2013). This allowed the different States, first under French (in)direct rule, then after Independences, to develop State-managed large-scale irrigation. Not a single drop was to go to the sea (Swearingen 1987), and 980,000 ha of large-scale irrigation schemes were developed in Algeria, Morocco and Tunisia from 1920 to 1980, providing access to irrigation water to hundreds of thousands of farmers (Benmoufok 2004; El Gueddari 2004; Al Atiri 2007).

These large-scale State-led projects masked the more discreet exploration and development of groundwater resources mainly by French settlers, who installed tube-wells from the late nineteenth century and beginning of the twentieth century onwards, often encouraged by the States themselves (Swearingen 1987; Côte 2002; Mamou and Kassah 2002). In Algeria, for instance, there were about 12,000 tubewells operational by 1960 (MRE 2009). The attention of the State was only episodically drawn to groundwater resources for two main reasons. First, the exploitation of groundwater resources was increasingly considered a profitable economic activity. ${ }^{1}$ Hydro-geologists undertook several studies to determine the potential yield of aquifers, and the economic interest of exploiting them for irrigation. These studies were followed by public programmes to drill tube-wells of considerable depth (100-200 m), for example during the 'artesian campaigns' in the oases in southern Algeria from 1856 to 1878 (Jus 1878), or the Moroccan programme in the 1920s to encourage private settlers (Célérier and Charton 1925). Second, by 1950 the first problems of overexploitation of aquifers appeared, especially in the coastal areas, where export-oriented horticulture had led to intensive groundwater use. This led to a drop in groundwater tables and even to problems of marine salt intrusion (Monition and de Lesguise 1954). Similarly, there were concerns about the loss of artesianism of sources, for example in oases in southern Tunisia (Mamou and Kassah 2002). In the early twentieth century, the

\footnotetext{
${ }^{1}$ From a more political perspective, Swearingen (1987) described how providing access to groundwater was thought to help pacify rebellious areas. In 1929, "wells of security" were installed to "fix to the soil" nomadic tribes in the Tadla area (Morocco): "As one newspaper editor paraphrased a Lyauté maxim: A well is worth a battalion".
} 
States reacted by incorporating groundwater resources in the public domain, by establishing procedures for the authorization and payment of water fees, and by conducting scientific studies to find solutions to the problems that were beginning to appear.

\subsubsection{Development of an Informal 'Groundwater Economy' (1980 to Date)}

From the early 1980s onwards, large-scale exploitation of groundwater for agriculture began in Algeria, Morocco, and Tunisia (Mamou and Kassah 2002; Hammani et al. 2009). The State initially encouraged groundwater exploitation to compensate for severe droughts by drilling deep state-owned tube-wells. Stimulated by expanding agricultural markets, on their own initiative, farmers rapidly took over and hundreds of thousands of private (tube-) wells were created (Mamou and Kassah 2002). Farmers increasingly preferred tube-wells to wells. The rapid expansion of tube-wells was due to declining water tables, but also to relatively cheap technologies both for installing them, which was generally handled by informal service providers capable of drilling deep tube-wells in only a few days, and for running them. The supply of energy for the tube-wells was often indirectly subsidized (butane gas in Morocco, electricity in Algeria and Tunisia), and the cost of equipping the tube-well (pump, engine) went down. Rural development programmes enabled the electrification of many tube-wells.

The flexible use of groundwater allowed the intensification and diversification of existing farming systems, and strengthened farmers' economic conditions. At the same time, farmers also became exposed to new risks, related for instance to fluctuating market prices for agricultural products. Intensive groundwater use in Algeria, Morocco and Tunisia enabled the development of a "vibrant wealthcreating agriculture', to which Shah (2009) - in the South-Asian context- referred to as the 'groundwater economy'. This represents a social-ecological system (see also Chap. 3), where socio-economic and biophysical dynamics are interdependent. The system combines two extremely complex systems: (1) the aquifer system, where 'virgin' recharge and discharge mechanisms and groundwater abstraction through tube-wells are intimately intertwined; and (2) a "people's irrigation economy' in which the initiative, investment, and management have come primarily from farmers" (Shah 2009). Farmers stimulated the development of a huge grey support sector through their ever-increasing demand for services, including the installation of tube-wells, the supply of inputs (seeds, fertilizers, herbicides and pesticides) and farm equipment (including irrigation equipment), counselling, and the sales of agricultural products (Poncet et al. 2010). This support sector in turn accompanied and even stimulated the expansion of groundwater-based agriculture.

The groundwater economy in Algeria, Morocco and Tunisia involves different territories. First, access to groundwater converted pastoral land, land dedicated to rain-fed agriculture, and even waste land into land used for irrigated agriculture, thereby creating new irrigation frontiers. Referred to as 'private irrigation', this is 
the context in which the most rapid and extensive growth of the groundwater economy occurred. From the mid-1990s onwards, the increasing use of groundwater was often accompanied by pressurized piped irrigation (particularly drip irrigation) in a mutually reinforcing process. Access to groundwater enabled farmers to increase their irrigated area without connecting to existing surface irrigation systems, and pressurized irrigation could be practiced in areas where surface irrigation could not (sandy soils, unsuitable relief).

Second, paradoxically, groundwater use also involved large-scale surface irrigation systems, which were affected by water scarcity. For instance, in the 100,000 ha Tadla irrigation scheme in Morocco, the number of (tube-) wells rose from a few hundred in the early 1980s to about 8,300 in 2008 (Hammani et al. 2009). This marked the transition from irrigation overwhelmingly based on flow irrigation to irrigation also, and increasingly, relying on pump irrigation (Shah 2009). This transition can be explained by the increasing demand for water for intensive agriculture in these schemes, as the droughts in the 1980s had affected the surface water supply, but also by the fact that the groundwater economy "liberated" farmers from State-led agriculture, in which even cropping patterns were imposed (Kuper et al. 2009). Nevertheless, farmers generally continued to use both water resources, as surface water was usually cheaper, and farmers were also keen to maintain a relationship with the State (ibid.).

Third, a number of community-managed irrigation schemes continued to rely on groundwater resources. This was the case of the khettara/foggara systems in the Atlas and Saharan areas, and of the irrigation systems in the piedmont, which relied on springs. A considerable number of public tube-well irrigation schemes also continued to function in Algeria and Tunisia. These were generally deep tubewells, installed on State initiative, with collective access to groundwater for farmers' associations. However, community-managed irrigation schemes are increasingly faced with individual initiatives of farmers or private investors installing tube-wells, either inside these systems, or (more often) in the vicinity of these systems. For instance, in southern Tunisia, Mekki et al. (2013) reported that both the irrigated area and the total water abstraction increased fivefold from 1970 to 2008. The appearance of pump irrigated 'modern' agriculture often jeopardized 'traditional' flow irrigated systems, sometimes leading to their destruction (Popp 1986).

\subsection{Magnitude of the Groundwater Economy Today}

\subsubsection{Observing a Furtive Groundwater Economy}

Official statistics on groundwater-based systems, and more particularly those pertaining to individual pump irrigation, are generally difficult to obtain. The data are fragmented and diffuse, mirroring the image of the furtive groundwater economy itself. The information is in the hands of different administrations, who 
commission private consultants to conduct surveys whose results are not always made public. The FAO Aquastat database, for instance, which we accessed on July 15th 2013, provided figures for groundwater-irrigated areas that date back to 2000 (Morocco, Tunisia), and 2001 (Algeria)! A scholar who wishes to understand the magnitude of the groundwater economy faces a number of problems, which we discuss further below: (1) the groundwater economy is often considered to be a private business by its protagonists, and the legitimacy of the State to even collect data is frequently challenged; (2) the diffuse, and often informal nature of the rapidly developing groundwater economy makes it an extremely complex system to observe; and (3) aquifer dynamics are complex, even more so when they are intertwined with human practices.

\subsubsection{A Furtive Economy}

The groundwater economy is mainly a private irrigation economy developed during a period when the dominant paradigm called for the State, already in the process of disengaging, to get out of the way of private initiative. Not only did the State install fewer public pumping schemes, but even controlling the development of individual wells and tube-wells was often impossible. "Illegal" private (tube-) wells, which are often not included in official statistics, account for the vast majority of pumping devices. Many actors of the groundwater economy are "invisible", since they crop and irrigate the land under informal contracts as lessees or tenants, while equally informal intermediaries provide inputs, credit, and sell their agricultural products (Daoudi and Wampfler 2010). In the Mitidja plain (Algeria), for instance, Imache et al. (2010) estimated that $23 \%$ of the volume of irrigation was used to irrigate horticultural crops grown by lessees whose presence is not officially acknowledged, through informal water transactions. Even when farmers declare their tube-well, they tend to make their declaration conform to current legislation, and not to field realities. This may lead to tube-wells installed inside wells, so they can be declared as wells. This also often leads to farmers under-declaring the depth of their tubewell. For example, a farmer we met in Kairouan (Tunisia) in 2012 had a 120-m deep tube-well, which he had declared as being $50 \mathrm{~m}$ deep. Fifty metres is the limit for water-lifting devices to qualify as 'surface wells', which were tolerated by the administration. As we met him after the Tunisian "revolution" in 2011, he was proud to show us his tube-well, which in his view almost qualified as an act of resistance against the previous regime: "in the past, I had to cover it with plastic, but now I am free to show you my tube-well". This is a good example of law breaking (i.e. ignoring the official ban on drilling beyond a depth $50 \mathrm{~m}$ ), but is also symptomatic of the continuous negotiation between the State and irrigators, which certainly influenced the expansion of groundwater use.

\subsubsection{Surveys Are Out of Date the Day They Are Published}

The 'atomistic' informal nature of the groundwater economy, which relies on individual and diffuse access to groundwater, along with its extremely rapid development makes it difficult to monitor (Shah et al. 2003; Moench 2007). In addition, in Algeria, Morocco and Tunisia, mixing resources is common; for 
example, in large-scale surface irrigation schemes most farmers also have access to groundwater through private pumps, or in Saharan oases, making it difficult to distinguish between areas irrigated with surface water or groundwater. Occasionally, extensive regional or national surveys have been undertaken to count the number of (tube-) wells and determine the areas irrigated by groundwater. A survey on 'private' irrigation financed by the World Bank was conducted in Morocco in 2002, while in Algeria a survey was conducted in 2009 (Bouchedja 2012), and in Tunisia in 2010. These surveys are often incomplete, and are out of date the day they are published. At any time, farmers may close wells which run dry, deepen them, or convert wells into tube-wells, while ever increasing numbers of farmers join the groundwater economy each day by installing new tube-wells. Others obtain access to groundwater through informal water transactions, which are difficult to account for without close observation. Then again, even when the number of wells and tube-wells is known, this does not provide information on groundwater use. Field observations in the Tadla (Morocco) revealed considerable differences in the use of similar tube-wells (depth, discharge, source of energy) between neighbouring small and medium-scale farmers (Kuper et al. 2003). The annual utilization rate varied from 600 to $1,870 \mathrm{~h}$, and the annual volumes pumped from 32,000 to $101,000 \mathrm{~m}^{3}$, depending on the crops grown, irrigation practices, the area served, and the number of farmers who relied on the tube-well. The inherent complexity of groundwater use means it is often estimated for regional water balances rather than established in the field.

\subsubsection{Overexploitation, an Established Fact?}

Aquifer dynamics are extremely complex and the values of different hydrological parameters vary considerably under different scenarios of change, including climate change, and human practices such as pumping. This makes modelling groundwater and predicting the behaviour of a particular groundwater system a difficult exercise (Rojas et al. 2010). Whether groundwater comes from renewable or nonrenewable sources, and to what extent specific aquifers are overexploited is the subject of lively debate (Konikow and Kendy 2005). While major uncertainties remain on the hydrological impact of recent rapid changes, including groundwater pumping, hydro-geologists agree that the "present development of agriculture is.. . unsustainable" (Leduc et al. 2007). River basin agencies routinely present graphs of declining groundwater tables. Perhaps more surprisingly, most groundwater users are also aware of the coming groundwater crisis (Bekkar et al. 2009), and some even anticipate their exit from groundwater-related agriculture. Groundwater resource overdraft is no longer an issue only pointed out by hydro-geologists (e.g. Llamas 1998), but has become common discourse. But up to now, this apparent consensus has not led to using existing information for better management of groundwater use in the region (Hammani et al. 2009). This pleads for more attention to be paid to the use of information, as much as to the production of information, and hence to obtaining more insights into the users' point of view of groundwater exploitation (Mitchell et al. 2012). 


\subsubsection{Official Figures: Redrawing the Irrigation Map in North Africa}

Despite the difficulties of obtaining data on the groundwater economy in Algeria, Morocco and Tunisia, and the doubt surrounding the accuracy and utility of such data, we synthesized - to the best of our knowledge - some figures based on the different national statistics (Table 23.1). This exercise is fraught with danger, and

Table 23.1 Official figures concerning the groundwater economy in Algeria, Morocco and Tunisia

\begin{tabular}{l|l|l|l}
\hline & Algeria & Morocco & Tunisia \\
\hline Total irrigated area (ha) & $1,006,198^{\mathrm{a}}$ & $1,458,160^{\mathrm{b}}$ & $404,375^{\mathrm{c}, \mathrm{d}}$ \\
\hline $\begin{array}{l}\text { Area irrigated by groundwater pumps (in ha and } \\
\text { as \% of total area) }\end{array}$ & $\begin{array}{l}883,004^{\mathrm{a}, \mathrm{e}} \\
88 \%\end{array}$ & $\begin{array}{l}615,881^{\mathrm{b}, \mathrm{f}} \\
42 \%\end{array}$ & $\begin{array}{l}258,547^{\mathrm{c}, \mathrm{g}} \\
64 \%\end{array}$ \\
\hline $\begin{array}{l}\text { Total annual renewable groundwater resources } \\
\left(\mathrm{km}^{3}\right)\end{array}$ & $7.1^{\mathrm{h}, \mathrm{i}}$ & $4.1^{\mathrm{j}}$ & $2.2^{\mathrm{k}}$ \\
\hline $\begin{array}{l}\text { Annual groundwater withdrawal for irrigation } \\
\left(\mathrm{km}^{3}\right)\end{array}$ & $8.1^{1, \mathrm{~m}}$ & $3.5^{\mathrm{j}}$ & $2.0^{\mathrm{k}}$ \\
\hline $\begin{array}{l}\text { Annual groundwater withdrawal for drinking } \\
\text { water }\left(\mathrm{km}^{3}\right)\end{array}$ & $1.6^{\mathrm{a}}$ & $0.4^{\mathrm{j}}$ & $0.4^{\mathrm{c}}$ \\
\hline $\begin{array}{l}\text { Number of overexploited aquifers/total number } \\
\text { of aquifers }\end{array}$ & $\begin{array}{l}\text { North: } \\
23 / 38^{\mathrm{i}} \\
\text { South: all }\end{array}$ & $57 / 99^{\mathrm{j}}$ & $71 / 273^{\mathrm{n}, \mathrm{o}}$ \\
\hline $\begin{array}{l}144,050 \\
\text { wells }\end{array}$ & $\begin{array}{l}62,967 \text { tube- } \\
\text { wells }\end{array}$ & $100,000^{\mathrm{b}}$ & $\begin{array}{l}137,709 \\
\text { wells } \mathrm{k}, \mathrm{p} \\
6,167 \text { tube- }^{\mathrm{a}} \\
\text { wells }\end{array}$ \\
\hline
\end{tabular}

${ }^{\mathrm{a}} \mathrm{MRE}(2011)$

${ }^{\mathrm{b}}$ MAPM (2012)

${ }^{\mathrm{c}}$ DGGREE (2006)

'The total irrigated area of 'intensive' irrigated agriculture in 2013 was 416,000 ha (DGGREE). The area irrigated by groundwater is certainly underestimated, as farms in public surface irrigation schemes $(138,248$ ha in 2006) may use groundwater

${ }^{\mathrm{e}}$ This includes the area irrigated by wells (316,198 ha) and tube-wells (486,806 ha) in small- and medium-scale irrigation schemes, and pump irrigation in large-scale irrigation schemes $(-80,000$ ha; Benblidia 2011)

fThis includes "private irrigation" (435,881 ha), and pump irrigation in large- as well as small- and medium-scale irrigation schemes $(-180,000 \mathrm{ha})$

${ }^{\mathrm{g}}$ This includes 180,283 ha of private irrigation and 78,264 ha of public tube-well schemes

${ }^{\mathrm{h}}$ Bouchedja (2012)

${ }^{\mathrm{i}}$ This includes $5 \mathrm{~km}^{3} /$ year of non-renewable or little renewable groundwater resources in the Sahara

${ }^{\mathrm{j}}$ Ziyad (2007), ABH (2011)

${ }^{\mathrm{k}} \operatorname{DGRE}(2005,2008)$

${ }^{\mathrm{l}}$ MRE (2009)

${ }^{\mathrm{m}}$ Value estimated on the basis of cropped areas and theoretical crop water requirements

${ }^{\mathrm{n}}$ TICET (2009)

${ }^{\circ}$ Tunisia identified a higher number of aquifers than the other countries as it privileged a local management perspective (Faysse et al. 2011)

${ }^{\mathrm{p}}$ According to the Ministry of Agriculture, only 94,691 out of 137,709 wells were 'equipped' with a pump/engine (DGGREE 2006) 
the figures should be interpreted with great caution. Despite these reservations, we feel this is a useful exercise, as it provides some idea of the comparative importance of the groundwater economy in the three countries. If considered in conjunction with more detailed local studies, these figures provide an interesting perspective of the rapidly evolving, informal, atomistic groundwater economy.

Three conclusions can be drawn from this table. Firstly, it shows the importance of the groundwater economy in these three countries. According to these data, the groundwater economy caters to more than 1.75 million ha of irrigated land (more than $60 \%$ of the total irrigated area), farmed by probably more than 500,000 farm holdings (293,033 farm holdings in Algeria alone). The countries regularly publish information on the substantial added value of irrigated agriculture for which groundwater has become indispensable. In Morocco, the High Commission for Planning (2008) stated that in an average year, the irrigated sector, while only accounting for $13 \%$ of the agricultural area, contributes about $45 \%$ of agricultural added value, and $75 \%$ of agricultural exports and accounts for $35 \%$ of rural employment. The irrigated sector is responsible for all citrus and sugar production, and supplies $80 \%$ of horticultural products, fodder and milk. Twenty per cent of meat and cereals come from irrigated areas. At the same time, the groundwater economy appears to benefit a minority of farmers. From the official agricultural census in the different countries, it can be deduced that only $20-30 \%$ of all farmers have access to groundwater.

Secondly, the official data show that the current status of aquifers is not good. More than half the aquifers in Algeria and Morocco, and about one quarter of the aquifers in Tunisia are overexploited, and the potential of aquifers in Tunisia is severely limited by salinity. All three countries rely to a considerable extent on groundwater resources, especially Algeria (88\% of the total irrigated area, Table 23.1) and Tunisia (64\%). Morocco (42\%) benefits from more generous (renewable) surface water resources. This is probably why, as opposed to Algeria and Tunisia, Morocco never developed many public tube-well schemes. In Tunisia public tube-well schemes officially still account for $30 \%$ of the pump-irrigated area. This figure is certainly overestimated, as farmers installed private tube-wells even inside public irrigation schemes. According to official statistics the groundwater economy in Algeria, Morocco and Tunisia is served by about 450,000 (tube-) wells for a total withdrawal for irrigation of $13.6 \mathrm{~km}^{3}$; these values are probably the most questionable figures in the table due to the difficulty of keeping track of the (tube-) wells, and of monitoring the withdrawals. In all three countries, farmers are increasingly turning to tube-wells, whereas the total number of wells is not progressing, or is even declining. Farmers are accessing deeper (confined) aquifers, where the supply - in the short term - is better, but where the water resources are even less renewable. Finally, some of the most rapidly growing irrigated areas were based on the mining of non-renewable groundwater resources (Margat 2008).

Thirdly, when comparing these data with earlier official data, (available on the FAO database) it appears that the groundwater economy has expanded at a remarkable pace. Nowhere is this clearer than in Algeria, where the irrigated area increased from 228,000 ha in 1985 to slightly over a million ha in 2011. While the latter figure 
may be optimistic, there is no doubt about the galloping development of Algeria's groundwater economy. Algeria's irrigation map was redrawn after the exploitation of huge groundwater reserves in the south, ranking the country second only to Libya in terms of available groundwater resources in Africa (MacDonald et al. 2012).

\subsubsection{Policy Measures}

Irrigated agriculture has been consistently and "disproportionately prominent in national water allocation policy discourse" in the Middle East and North Africa's political economies (Allan 2007). Irrigated farming was not only a "deeply entrenched social phenomenon" (ibid.), but was also considered to be a political priority in building the independent Nation (Akesbi and Guerraoui 1991). Policies initially focused on building dams for surface irrigation but, from the 1970s on, groundwater resources were included in water master plans, as surface resources gradually became insufficient (Al Atiri 2007).

For many years, groundwater was mainly seen as a complementary resource that could be used for more intensive irrigated agriculture. Following the 1992 Dublin conference, international discourse on integrated water resources management gained importance in the Mediterranean area and coincided with increasing awareness of the limits of existing water resources (Margat and Vallée 1999). These debates inspired recent water laws and strategies in Algeria, Morocco and Tunisia, leading to institutional reforms (e.g. the creation of river basin agencies), and to a series of measures promoting the rational use of water (El Alaoui 2006; Al Atiri 2007; Benblidia 2011). Basically, the idea was to promote water demand management as opposed to a supply-based approach, as the latter had led to ever-increasing pressure on water resources (Margat and Vallée 1999). Agriculture was specifically targeted as a sector in which water was 'wasted.' Water demand management meant identifying possible ways of saving water, so water could be used more productively, while decreasing the existing pressure on water resources. However, the different economic, regulatory and participatory instruments proposed and debated never focused on water demand management alone, and the different states continued to explore ways to increase the water supply, for example through desalination (Benblidia 2011).

Faysse et al. (2012) conducted an inventory of the different policy instruments focused on groundwater, implemented and discussed in Algeria, Morocco and Tunisia on the basis of the expected impacts: (1) direct regulation of the water demand (authorization, control of extracted volumes); (2) incentives for water demand management (tariffs, subsidies for micro-irrigation); and (3) measures for increased water availability (desalination, groundwater recharge). In addition, a limited number of initiatives on participatory instruments were identified, including groundwater users associations in Tunisia, and aquifer contracts in Morocco (ibid.). There has been little public debate on the environmental, social, and economic sustainability of the groundwater economies in the region. The question is whether the future pathways of these groundwater economies only concern farmers who are 
currently overexploiting them? Or do they also concern farmers who currently have no access? When dealing with groundwater overexploitation today, it is probably more realistic to first involve farmers who pump large volumes. If the stakes related to equity, rural poverty or agricultural productivity were taken into account, the debate could extend to rural areas, or even to society at large.

After more than a decade of lively debate and policy initiatives promoting water demand management, paradoxically, irrigated agriculture appears to be no longer in the 'dock' for wasting water, even though in the meantime the pressure on groundwater resources has increased. This increased pressure may be partly due to recent ambitious agricultural policies (e.g. the 2008 Green Morocco Plan), which promote modern "excessively intensive" agricultural models with increased pressure on water resources (Akesbi 2014). In parallel, the agricultural sector started several subsidy programmes for water saving irrigation technologies, especially drip irrigation. The amount of water saved as a result of these programmes has rarely been evaluated (Benouniche et al. 2014), but the programmes were probably essential in providing agriculture with a more positive image of "efficiency, productivity and modernity" (Venot et al. 2014). Through the "alignment of farmers' interests and those of the political class" (Allan 2007), solutions are once again being sought in supply management approaches (desalination, inter-basin transfers) or in technological inventions, such as water saving irrigation technologies.

\subsection{Illustrating the Rapid Massive Development of North Africa's Groundwater Economy}

We use two contrasting case studies to illustrate the diversity of the different local groundwater economies encountered in North Africa, focusing on the three issues mentioned in the introduction, i.e. the apparent contradiction of groundwater as an "enabler of an important rural socio-economic transition", used with "short-term water-using practices" and presided over by passive political economies (Allan 2007). The first case study concerns the Biskra district in the Algerian Sahara (less than $150 \mathrm{~mm}$ of rain annually), where the rapid irrigation development relies almost exclusively on non- or little renewable groundwater resources (Fig. 23.1). The second case study was conducted in the rich agricultural Saiss plain in northwestern Morocco (with 400-600 mm rainfall regime), where farmers turned to irrigated agriculture by exploiting a rich but overexploited aquifer system (Fig. 23.2).

\subsubsection{Biskra: Why Deal with the Problems Now?}

Groundwater experts put North African countries such as Algeria and Libya on the map as the most water-rich countries of the continent thanks to enormous, but not very actively recharged, sedimentary Saharan aquifers (MacDonald et al. 2012). 


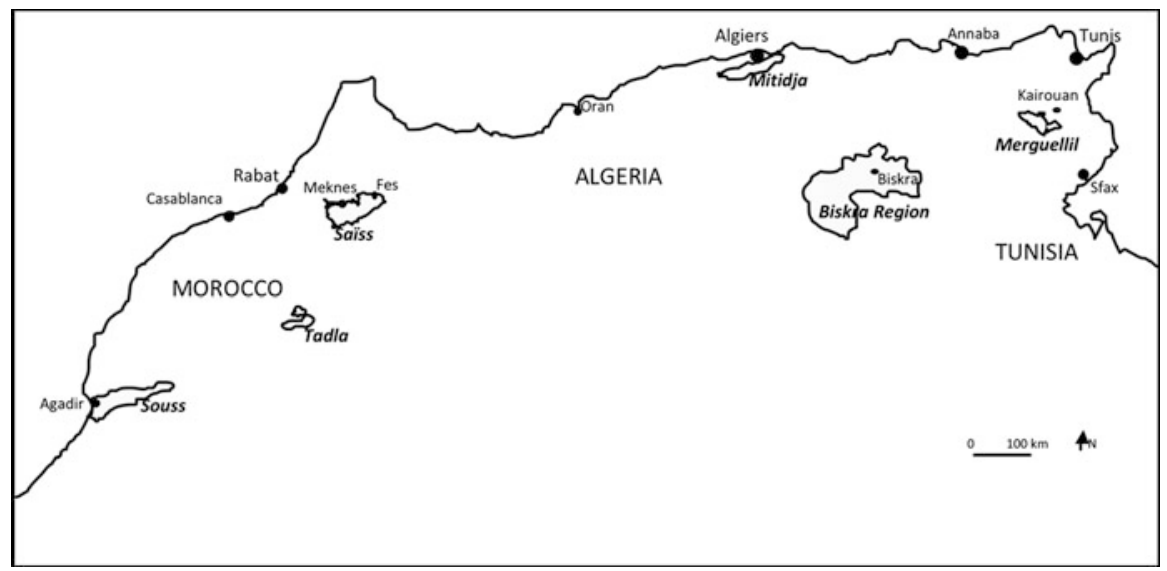

Fig. 23.1 Location of the case studies in North Africa

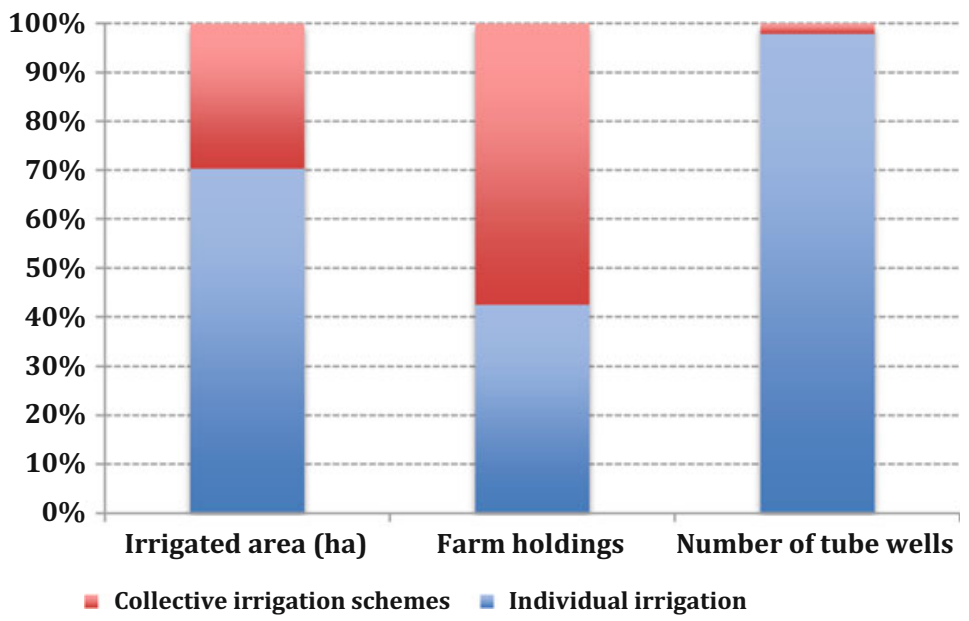

Fig. 23.2 Private and collective irrigation in the Biskra district (Source: MRE 2009)

These countries did not stand out in FAO irrigation statistics in the past due to limited development of State-led irrigation, but rapid private irrigation expansion linked to groundwater is changing the outlook and scale of the irrigated sector. In Algeria, groundwater is shifting the balance between traditional irrigated areas in the North, and rapidly developing irrigated agriculture in the Sahara.

Oases had been declining since the sixteenth century with the demise of TransSaharan trade when an astonishing agricultural revival started in the early twentieth century linked first to the exploration of new artesian tube-wells, and more recently to pump irrigation. Groundwater allowed the rapid expansion of palm groves in the Algerian Sahara, which increased from 5.5 million palm trees in 1959 to 12 million 
in 2000, and to 17 million in 2011 (Côte 2002; Benziouche et Cheriet 2012). The rapid agricultural development of the Biskra district made it one of the most important Saharan agricultural regions in Algeria. The irrigated area increased fivefold from 16,615 ha in 1969 to 83,350 ha in 2008 and $94 \%$ of the irrigation water is currently supplied by groundwater through 4,293 wells and 9,075 tubewells (MRE 2009).

While palm groves were traditionally irrigated through community-managed collective irrigation schemes around artesian wells, springs, or diverted river flow, more than $70 \%$ of the total irrigated area is now qualified as private or individual irrigation areas (Fig. 23.2). The figure confirms the rapid expansion of private irrigation, which took place mostly outside the traditional oases. However, collective irrigation schemes continued to serve almost $60 \%$ (19,305 farms) of the total number of irrigated farm holdings in the Biskra district. These collective schemes are served by powerful tube-wells $(>100 \mathrm{l} / \mathrm{s})$ or more rarely, by artesian wells, in some cases enhanced by surface water or springs. This explains the limited number of tube-wells in these schemes, according to official data (Fig. 23.2).

In the next two sections, we will show first how groundwater was integrated into the existing farmer-managed surface irrigation system of the oasis of Sidi Okba through a complex mix of private and collective (tube-) wells. The state played an important role in unlocking the access to groundwater. We will then present the new irrigation frontiers, outside of the oases, where groundwater is accessed through private tube-wells enabling commercial date production and greenhouse horticulture.

\subsubsection{Traditional Oases: Integrating Groundwater in the Existing Farmer-Managed Irrigation System}

Access to water resources in traditional oases is rather complex. We analysed changes in access to groundwater in the 970 ha Sidi Okba palm grove, situated in the Biskra district. This mythical palm grove, laid out around the 686 mosque commemorating the Arab conqueror Oqba Ibn Nafaa, was traditionally supplied by surface water (Oued El Abiod), but increasingly relies on groundwater (Fig. 23.3). Officially, the palm grove is irrigated by surface water (Foum El Gherza dam) and five functioning state-created tube-wells managed by a farmers' cooperative. However, there is also a large number of individual or community-owned collective tube-wells. In 2013, a total of 71 State and private tube-wells (collective or individual) were counted of which only 42 were functioning.

Access to groundwater started in the 1920s, when farmers dug hand-operated wells, which they mechanized from 1950 onwards (Fig. 23.3). These wells were progressively abandoned in the 1960s and 1970s. In 1979, access to the confined aquifer was initiated by the State to compensate for dwindling surface water resources following droughts. The State had two-tube-wells drilled to great depths (632 and $807 \mathrm{~m}$, respectively), followed by six more later on. Farmers followed suit and drilled 63 collective and individual tube-wells.

The figure illustrates three main issues of Biskra's groundwater economy. Firstly, the different groundwater resources were successively unlocked over a 


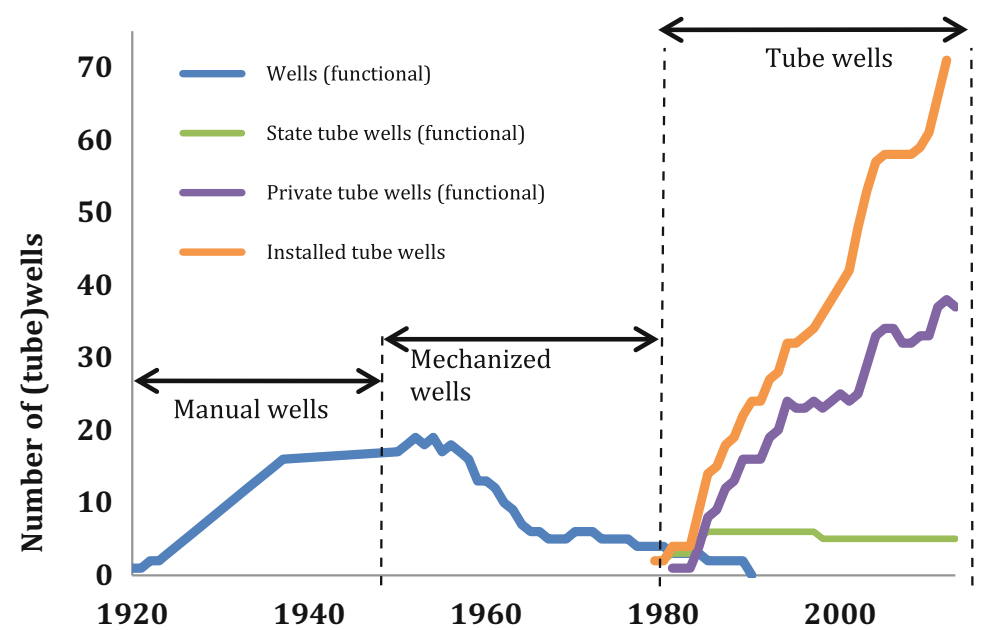

Fig. 23.3 Development of wells and tube-wells in the Sidi Okba palm grove (Biskra region)

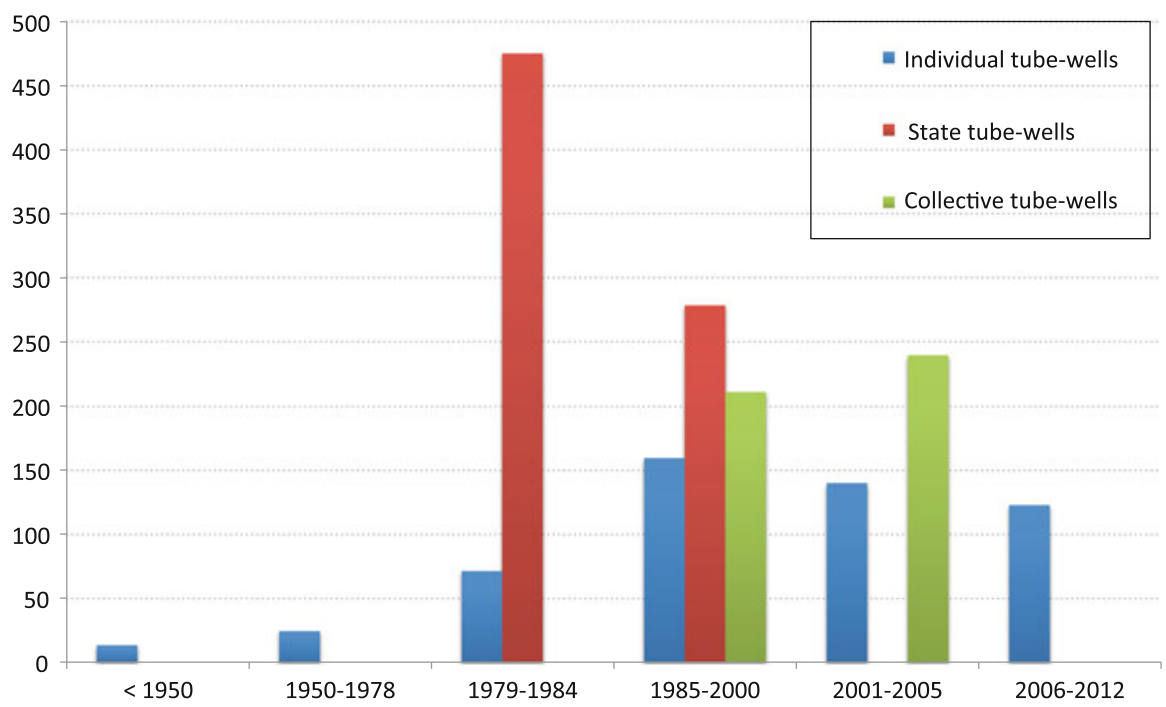

Fig. 23.4 Changes in the depth of (tube-)wells drilled in the Sidi Okba palm grove (Biskra region)

long period of time. Farmers look for water at increasing depth, and as a result, they may even change an aquifer's behavior (Fig. 23.4). While they initially exploited the phreatic aquifer using 10-30-m deep wells or relatively shallow tube-wells $(50-70 \mathrm{~m})$, they started drilling deep tube-wells in the early $1980 \mathrm{~s}$ thereby accessing the first confined aquifer. The State-led drilling of deep tube-wells having a high discharge, and delivering relatively good quality water, prompted farmers to 
drill individual tube-wells to a depth of 100-150 m. Some even drilled to a depth of $200 \mathrm{~m}$ for individual tube-wells, and to $280 \mathrm{~m}$ for collective tube-wells. From 2002 onwards, the State managed to impose some norms on the depth of tube-wells, at least on those that were subsidized: individual tube-wells should not exceed $150 \mathrm{~m}$, and collective tube-wells should not exceed $250 \mathrm{~m}$. Groundwater also "liberated" farmers, and especially the former sharecroppers, to go beyond the frontiers of the traditional palm grove, and settle on new lands to establish new farming systems, including commercial dates and horticulture.

Secondly, the State as well as the irrigation community continued to play an important role in managing groundwater, and access did not become entirely private. In the Sidi Okba palm grove, 30 tube-wells (out of 71) were either installed or subsidized by the State, of which 12 were collective tube-wells. The existing farmer-managed irrigation cooperative was able to integrate progressively (part of the) groundwater resources in the collective management of the surface irrigation system. The cooperative continued to distribute surface water, but also included the state tube-wells in the water distribution programme. The irrigation community installed a further 10 collective tube-wells, which were shared by neighbours or relatives. The community even created three larger informal tube-well associations (using four collective tube-wells), where farmers were supplied with water according to the shares they had in the tube-well. This collective organization (20-60 members per association) is perhaps due to the fact that the irrigation community already managed a collective surface irrigation scheme at the time. Collective action is probably also linked to the high cost of accessing confined aquifers at substantial depth. However, in the past 10 years, only individual tubewells were drilled in the palm grove, encouraged by individual State subsidies.

Thirdly, farmers faced many hazards in accessing groundwater. They progressively abandoned the 37 wells in the palm grove, due to the drop in groundwater levels, and the increasing salinity of the phreatic aquifer. Another problem was the limited know-how of private companies who improvised the installation of tubewells in the 1980s and 1990s. Some tube-wells became obsolete after only functioning for a few years. Twenty-nine (out of 63) individual and collective tubewells drilled between 1979 and 2000 stopped functioning (Fig. 23.3), mainly due to the poor quality of the equipment (tubing, pump). The State-installed tube-wells also often broke down because of age and the high cost of repairs. Three out of eight tube-wells in this category are no longer functional today.

\subsubsection{Outside the Oases: Exploring New Irrigation Frontiers}

Outside the traditional oases, palm groves no longer followed the classical threestage oasis system, but were new mono-cropped plantations focused on the production of deglet nour, a readily marketable date for the domestic and export market. More surprisingly, groundwater also enabled new farming systems, in particular greenhouse horticulture (tomatoes, peppers, chillies, aubergines, (water) melons), which arrive early on the domestic markets thanks to favourable climatic conditions. Greenhouse horticulture started in the 1980s, and expanded rapidly (Khiari 2002). Recent figures from the Ministry of Agriculture mention almost 
100,000 greenhouses (about 4,000 ha) in 2010. New palm groves and greenhouses spread rapidly in the Biskra district, following the availability of groundwater resources. The region ranks second in Algeria in agricultural production (around 1.24 billion $€$ in 2012), only behind another Saharan region (El Oued). In 2012, Biskra accounted for $37 \%$ of dates grown in Algeria, and for $25 \%$ of tomatoes.

The question is what are the limits to the development of this Saharan groundwater economy? On the one hand, official data imply serious overexploitation of groundwater resources, and ever-increasing numbers of tube-wells. Groundwater use for irrigation in Biskra is estimated to be around $1.2 \mathrm{~km}^{3}$ per year (MRE 2009), which is $467 \%$ of the volume of the renewable groundwater resources that can be exploited $\left(0.26 \mathrm{~km}^{3} /\right.$ year). However, the different actors largely ignore this "safe yield" (Alley and Leake 2004), and continue to overexploit the different aquifers, including the Continental Intercalaire aquifer, which is non- or little renewable, but represents an enormous reserve $\left(91,900 \mathrm{~km}^{3}\right.$; MacDonald et al. 2012). Farmers are confronted with decreasing groundwater tables, and frequently deepen their tubewells.

On the other hand, the Saharan groundwater economy continues to grow rapidly, mainly through private investment and 'resource pooling' (Amichi et al. 2013). Farmers come from hundreds of kilometres away, attracted by the abundant land and water resources of the area, and bring know-how, energy and financial resources. These integrative farming systems continue to attract new financial, and human resources which, in turn, further extend the irrigation frontiers of Saharan agriculture. The State contributed to this development enabling access to land and water by providing agricultural subsidies, but also, and perhaps most importantly, by developing the basic infrastructure to ensure the logistics for intensive agriculture, and support the newcomers (wholesale markets, roads, health facilities and schools, electricity supply).

This illustrates not only Biskra's attraction for private investment in agriculture, but also how private investment is supported by ambitious public policies and investments aiming to "transform the Algerian Sahara into an agricultural Eldorado" (Otmane and Kouzmine 2013). In a survey of 150 farmers, $84 \%$ declared they had made substantial investments since 2000 (plantations, pumping station, drip irrigation), and $52 \%$ said they had obtained subsidies for these investments (MRE 2009). However, this mainly concerned established farmers. Most informal actors, particularly in the horticultural sector (tenants, lessees), may not even have been interviewed, as they are generally not registered as farmers. They manage without subsidies, because of buoyant agricultural markets and a strong national demand for fresh vegetables.

In sum, Biskra's thriving groundwater economy continues to develop at a breathtaking pace both inside and outside the traditional oases. The limiting factors which generally limit the development of agriculture (markets, capital, labour, land, water) will surely surface sometime, but in the meantime, business as usual - that is rapid expansion - is likely to continue. 


\subsubsection{Saiss: "He Has Committed the Crime Who Profits by It" (Seneca)}

The Saiss plain is a well-known rich agricultural area in Morocco in the vicinity of Fes and Meknes, covering about 220,000 ha. In the past, the Saiss plain was known for rain-fed crops (cereals, vineyards, olive trees). Some small communitymanaged irrigation schemes, which depended on springs, made it possible to irrigate certain crops (tobacco, fodder, vegetables). The Saiss always attracted newcomers because of its rich productive resources, and its proximity to Fes and Meknes. During the first half of the twentieth century, French settlers occupied some of the best lands accounting for about one third of the total surface area. Some stayed until 1971. This land was then partly redistributed to landless farmers or labourers who formerly worked on colonial farms. Some lands were grouped in agrarian reform cooperatives under close State supervision, and some were converted into State farms. Both types of agrarian structures disappeared over the past 10 years following structural reforms and State disengagement from direct agricultural production.

Droughts in the early 1980s along with a liberalisation of the agricultural sector prompted a series of rapid transformations whereby the groundwater economy rapidly gained momentum. There was a tremendous increase in pump-irrigated area, but also a decrease in the area irrigated by small-scale surface irrigation schemes. A survey by the Ministry of Agriculture in 2012 showed a total irrigated area of 49,677 ha (out of 220,000 ha), of which 45,316 ha depended on pump irrigation. Today, irrigation caters principally for orchards (olives, plums, peaches, apples), and vineyards, horticulture (onions, potatoes), and fodder crops.

Saiss' rich aquifer system is composed of a phreatic aquifer and the Lias confined aquifer; its potential was explored early on, and some (tube-)wells were installed during the protectorate. According to the river basin agency, groundwater tables have decreased considerably (ABH 2011). Groundwater levels in the phreatic aquifer, generally between 10 and $40 \mathrm{~m}$, decreased by about $10 \mathrm{~m}$ between the early 1980 s and 2005, with a sharper decline after 2000 when water levels decreased by about $1 \mathrm{~m}$ per year. The decline in groundwater tables was even more marked in the confined aquifer. In the west (Meknes area), the decline was about $65 \mathrm{~m}$ between 1979 and 2004, i.e. $2.6 \mathrm{~m}$ per year. In the east, the decline was about 20-25 m over the same period.

Field observations conducted in an area of 4,153 ha in the Saiss near the town of El Hajeb illustrate the rapid transformations (Fig. 23.5). In 1989, the area was characterized by the contrast between an irrigated State farm (1,374 ha) and a large collective agrarian reform cooperative (1,888 ha), growing rain-fed cereals. In the cooperative, the land was not attributed to individual farmers, and the assignees basically had the status of labourers working under State supervision. There was no room for private initiative to grow other crops, or change to irrigated agriculture, whereas on a nearby smaller agrarian reform cooperative (340 ha), assignees had been attributed individual plots. They were supposed to work the land together with other assignees, but in practice managed to progressively install wells to irrigate 
(a)

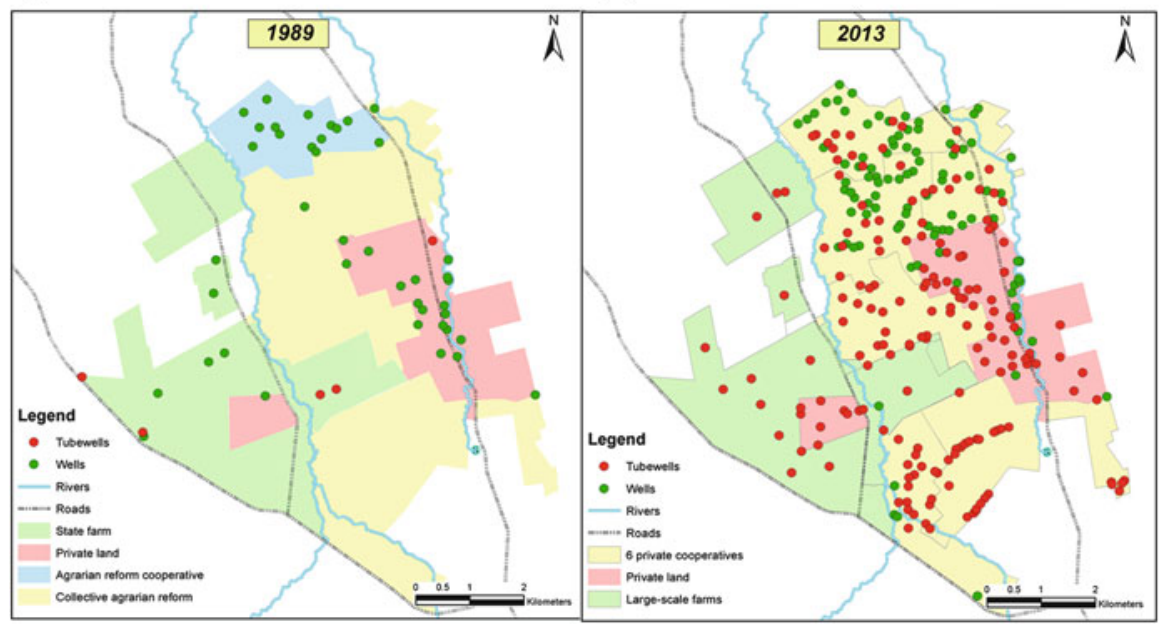

Fig. 23.5 Maps showing the proliferation of wells and tube-wells in the study area (4,153 ha) in the Saiss in 1989 (a) and 2013 (b)

part of their land in the context of State disengagement. Farmers on private land in the study area (551 ha) also installed wells. In 1989, the total number of pumping stations in the study area was 67 , of which 62 were wells, i.e. a density of about 1 (tube-) well for every 62 ha.

In 2013, the situation had drastically changed due to liberalisation. The State farm had been split in two, and leased out to private investors, who continued pump irrigation for orchards and vineyards. In 1991, the collective agrarian reform cooperative was split into small cooperatives with individual plots attributed to the assignees. Assignees diversified cropping patterns, and progressively gained access to groundwater through wells. In 2005, a government decree set off a process of land privatization of the agrarian reform cooperatives; once they had paid off all their debts, assignees could obtain a private land title. During this process, a lively land market emerged, resulting in the massive arrival of newcomers to these oftenrich lands. Assignees sold part of their land to pay their debts; some even sold all of their land. Large numbers of farmers (especially newcomers) joined the groundwater economy, but this time mainly through tube-wells which accessed both aquifers. The groundwater-based agricultural boom had considerable consequences for the groundwater availability. In 2013, half the wells (96 out of 193), mostly belonging to former assignees, were no longer functional, largely because they had run dry. But sometimes the farmers did not have the resources to make them function because they had ventured into more risky market crops, and ended up with debts. Other assignees managed to install tube-wells and ensure their access to groundwater. Newcomers generally invested in orchards, which required a tubewell usually with a drip irrigation kit. The total number of functional pumping 
stations amounted to 275 , of which 178 were tube-wells. The density of (tube-) wells in this study area increased to 1 (tube-)well for every 15 ha.

The antagonism between newcomers and local farmers is nowhere more clearly expressed than in the former agrarian reform cooperatives, where different farming models exist side by side. While most of the former assignees practise diversified cropping (cereals, horticulture, fodder) and both irrigated and rain-fed agriculture, newcomers prefer mono-cropped irrigated trees. The assignees mostly rely on wells, and have increasing difficulty in running their well, while the newcomers largely invest in tube-wells. Most of the local farmers, who were previously assignees in the different agrarian reform cooperatives, therefore tend to blame the newcomers, who are referred to as "investors", "buyers", or simply as "foreigners" (to the area), for causing their wells to run dry.

In two former cooperatives in the study area (here referred to as Alif and Ba), we investigated this mounting feeling of inequity in access to groundwater. To our surprise, the vast majority of farmers did have access to groundwater (respectively $88 \%$ and $75 \%$; Table 23.2), which, in other regions in North Africa, had been shown to be a first order inequity where this rate is usually much lower (Hammani et al. 2009). This high rate was probably for the following reasons: (1) the phreatic aquifer was rather shallow, particularly in the 1980s and 1990s; (2) farm holdings were relatively large compared to Moroccan standards, due to the recent distribution of land; (3) some assignees obtained access through tenancy arrangements, whereby the tenant or lessee obtained the land for a period of 5-6 years, and installed a (tube-)well, which reverted to the owner once the lease ended; and (4) the State subsidized the access to groundwater and the irrigated agriculture depending on groundwater.

A second order inequity concerned the pump equipment of farmers. The wells of most assignees were not adequately equipped (second-hand engine, vertical axial flow pumps), and could consequently only irrigate about 1-2 ha of land (mainly onions or potatoes). In addition, many of the wells of the assignees are running dry (about $50 \%$ and $25 \%$, respectively in both cooperatives; Table 23.2). Newcomers, on the other hand, used well-equipped tube-wells, and could easily irrigate 5-8 ha

Table 23.2 Access to groundwater of farmers in agrarian reform cooperatives Alif and Ba (Saiss plain)

\begin{tabular}{l|l|l}
\hline & Cooperative Alif & Cooperative Ba \\
\hline Surface area & 340 ha & 392 ha \\
\hline Number of farmers & 33 & 51 \\
\hline Number of farmers having access to groundwater & $29(88 \%)$ & $38(75 \%)$ \\
\hline Number of tube-wells & 12 & 19 \\
\hline Number of wells & 43 & 31 \\
\hline$\quad$ Functional & 22 & 23 \\
\hline$\quad$ Non-functional & 21 & 8 \\
\hline Irrigated area & $33 \%$ & $41 \%$ \\
\hline Rainfed area & $67 \%$ & $59 \%$ \\
\hline
\end{tabular}


of orchards. The cost of a fully equipped tube-well was $15,000-25,000 €$. The newcomers often had an off-farm income and usually obtained subsidies for investments. As a consequence, in the Alif cooperative, almost all farmers had access to groundwater but only one third of the land was irrigated. In the $\mathrm{Ba}$ cooperative, fewer farmers had access to groundwater but the percentage of irrigated land was slightly higher $(41 \%)$. The newcomers had more land (53 ha of arboriculture) than in the Alif cooperative (6 ha of arboriculture), which explains the difference in irrigated area.

Groundwater use is likely to increase in the near future, as tube-wells progressively replace wells. Tube-wells in the study area pump at least twice as much water (up to $40,000-65,000 \mathrm{~m}^{3} /$ year) as wells. The extra volumes of water available will likely extend the irrigated area, as almost two-thirds of the area is not yet irrigated. Moreover, newcomers have a mainly economic view of agriculture, with offensive strategies to maximize profits (Bekkar et al. 2009).

A third order inequity in the study area related to the economic situation of different social categories of farmers. Assignees had problems obtaining the other agricultural inputs required for irrigated agriculture, which limited their use of groundwater. This has an impact on the volume of water extracted by each category (Fig. 23.6).

Figure 23.6 shows that $3.6 \%$ of the farmers ( $>20$ ha) own more land $(44 \%)$ than $82.5 \%$ of the farmers ( $<10 \mathrm{ha}$ ) who own only $40.3 \%$ of the land. In the literature, this well-known skewed landownership is rarely interpreted in terms of the differential contribution of these farm holdings to the overexploitation of groundwater. Instead, this overexploitation is generally attributed to the agricultural sector as a

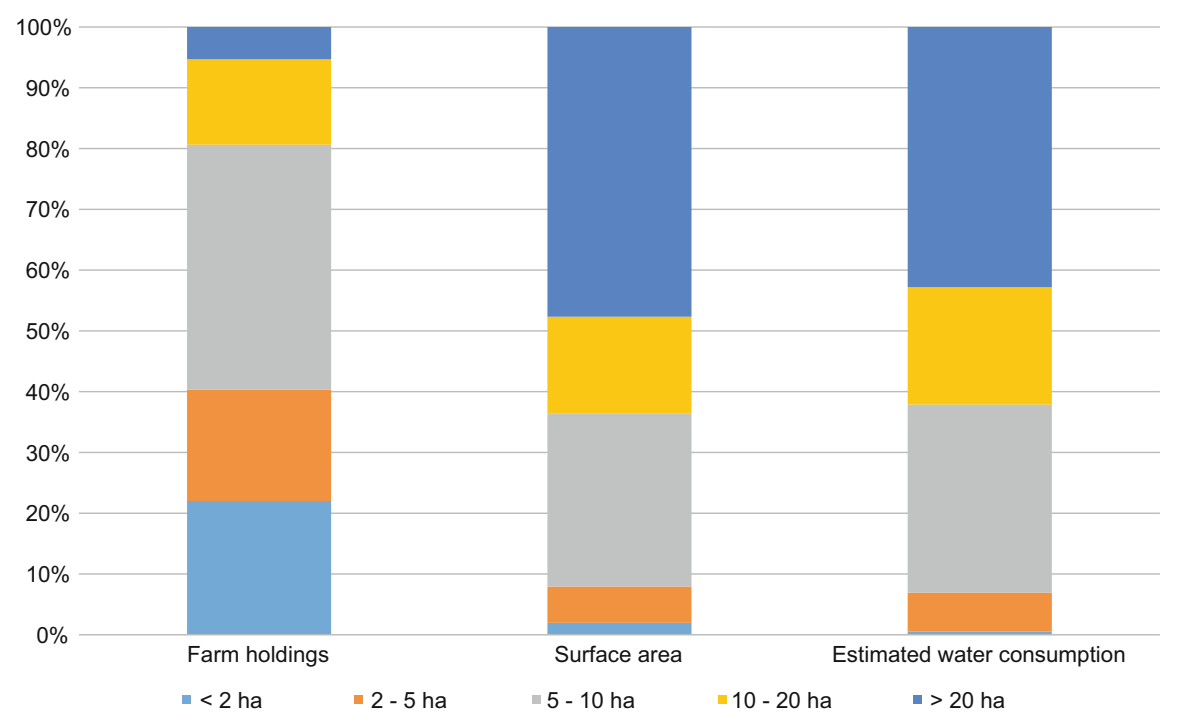

Fig. 23.6 Estimated water consumption (in \%) per class of farm holding in the study area, located in the Saiss 
whole. Distinguishing the contribution of the different categories of farmers to overexploitation is not easy due to complex agrarian structures and the mobility of farmers, and farmers' irrigation practices, which may lead to fourfold differences in irrigation volumes per ha (Benouniche et al. 2014). This explains the question mark in Fig. 23.6, which we are addressing in our on-going research. In the context of groundwater overexploitation, the question is then, who benefits from groundwater use, and who loses out?

\subsection{Three Issues Related to the Rapid and Massive Development of Groundwater Use}

\subsubsection{Will Overexploitation Continue? Current Groundwater Use Practices in North Africa's Groundwater Economies}

Current groundwater use practices have led to overexploitation of a large number of North Africa's aquifers, including some non- or little renewable aquifers. Due to the interplay between the different pathways of local groundwater economies, and the hydraulic characteristics of specific aquifers supporting them, groundwater practices will evolve differently in different situations.

Three main types of groundwater economies can be identified. First, the established medium-sized groundwater economies in northern and central Morocco, Algeria and Tunisia are based on renewable, but overexploited, groundwater resources, sometimes in addition to surface water resources which are exploited in existing irrigation schemes. Most of these groundwater economies have existed for more than 30 years, and each supports several tens of thousands of ha of irrigated agriculture. The groundwater economy of the Souss (Morocco) is probably the oldest and most threatened of all due to the marginalization of certain types of farming and social conflict (Popp 1986; Houdret 2012), brought about by a long history of intensive agriculture (orange trees, horticulture), and limited rainfall and recharge. But tensions have appeared even in more recent groundwater economies with higher precipitation rates like the Mitidja, in Algeria (Imache et al. 2010), Merguellil, in Tunisia (Leduc et al. 2007) or the Saiss (this study).

Second, the burgeoning groundwater economies of the Saharan areas, for example Nefzaoua (Tunisia) and Biskra (Algeria), are based on the exploitation of huge mostly non-renewable groundwater resources. Water is mined in quite a similar way as in the nearby oil fields (Margat 2008), while the local groundwater economy incorporates increasing numbers of farmers and other supporting actors in the current agricultural boom (Côte 2002; Mekki et al. 2013).

Third, minor volatile groundwater economies depend on often-overexploited small aquifers. They can be distinguished from the first type by their smaller size, which brings the tipping point beyond which a groundwater economy enters in a crisis situation much closer. Coastal horticultural groundwater economies are a typical example. Taking advantage of temperate climatic conditions, light soils and 
shallow groundwater, horticulture is widespread in many locations along the Atlantic and Mediterranean coasts. This led to many critical situations, particularly seawater intrusion, for example around Casablanca (Morocco) in the 1950s, around Azemmour (Morocco) in the 1980s (Berahmani et al. 2012), and north of Sfax (Tunisia) in the 1990s (Trabelsi et al. 2005). So far mainly individual adaptive strategies have been observed. Farmers reacted by piping good quality water in from nearby areas to continue horticulture, but in many cases had to change cropping systems by switching to more salinity tolerant crops or even quit (Berahmani et al. 2012). Local actors also looked to the State to save these groundwater economies, by providing additional surface water resources. However, as yet, there have been no 'success stories' concerning the restoration of the balance of such groundwater economies.

These North African aquifers can be positioned in the successive temporal stages of the rise and fall of groundwater economies, if adopting the frameworks of Shah et al. (2003) and Llamas and Martinez-Santos (2005). These frameworks propose a sequence in the life cycle of a groundwater economy, starting with a first stage in which the groundwater economy slowly emerges ("silent" revolution). The second stage corresponds to an era of groundwater-based agricultural prosperity. In the third stage, the first signs of groundwater overdraft or degradation become apparent, but farmer lobbies generally successfully defend the considerable interests generated by the groundwater economy. During the fourth stage, the decline in the groundwater economy causes social conflict. Conservation lobbies may prevent the groundwater economy entering this stage.

Most established medium-sized, partly renewable, groundwater economies are already positioned beyond the middle of the curves, meaning that there are early symptoms of groundwater overdraft with farmer lobbies defending their share and pushing the government to look for additional supplies, as is the case in the Saiss (Morocco), in the Mitidja (Imache et al. 2010) and in the Merguellil (Leduc et al. 2007). In the case of the Souss, clear signs of decline and social conflict are already apparent (Popp 1986; Houdret 2012). As in South Asia, these groundwater economies generally reached the later stages of the curves in less than 40 years. In these established groundwater economies, overexploitation will probably continue for the time being, while coalitions of privileged farmers and the State actively search for additional water resources, for example through desalination or interbasin water transfer.

The Saharan groundwater economies appear to be stably positioned in an earlier stage of the curves, that is in the stage of the groundwater-based agrarian boom. In these aquifers, there are signs of overexploitation; in some confined aquifers the water tables have dropped as much as $100 \mathrm{~m}$ in the past 20 years (MRE 2009). However, the water reserves are huge, and few actors appear to be worried about the finite nature of groundwater resources. It is hard to see how, in the context of the alignment of interests between the States promoting agricultural growth, and the different private actors with direct economic and social interest in these new irrigation frontiers, overexploitation will even remain at current levels. As with 
other mining resources, the question will then be how the benefits of such unsustainable groundwater economies will be reinvested.

Finally, some of the minor groundwater economies, such as the coastal horticultural systems, have already reached the final stages of their life cycle. Dealing with overexploitation in such situations could be a good test case for managing groundwater resources sustainably, as the size of these economies is limited. Technical solutions (artificial recharge, pumping barriers) that exist to deal with this issue will need to be embedded in a larger management framework negotiated with all the actors. Otherwise short-term water use practices are likely to continue (Llamas and Martinez-Santos 2005).

While farmers and public institutions agree on the general overdraft in the different aquifers, ${ }^{2}$ no supporting coalitions have emerged to deal with groundwater overexploitation (Faysse et al. 2012). Groundwater overdraft had dramatic shortterm consequences in some specific aquifers, but actors reacted individually or looked to the State to supply more water. In all other groundwater economies, to most local actors the crisis appeared far away. Proposed measures to deal with the crisis, through aquifer contracts for instance, mostly concerned increasing water supplies, through desalination units, inter-regional water transfer, or the construction of dams. Water saving in agriculture was promoted by subsidizing irrigation technologies such as drip irrigation. In reality, drip irrigation may even increase water demand as farmers turn to more intensive agriculture or extend the irrigated area (Berbel et al. 2013; Batchelor et al. 2014). The question is what will be the consequences of current water use practices, and how long will it take to deal with the looming groundwater crisis?

Alley and Leake (2004) took a long-term and multi-perspective view of "sustainable" groundwater development, including the environmental, economic and social consequences. They showed that groundwater use might go through stages that are environmentally unsustainable, but that propel social and economic development which would not have been possible without such use. This means that groundwater use should be thought out and, perhaps more importantly, negotiated in all the different stages in the life cycle of a groundwater economy. This is very difficult due to the State interest in increasing agricultural productivity, the inherent characteristics of the rapidly expanding and diffuse groundwater economy, and existing social power relations. However, putting off dealing with these issues may lead to extremely difficult situations, given the economic, social and political proportions that groundwater economies have taken.

\footnotetext{
${ }^{2}$ Issues related to groundwater pollution in North Africa are widely acknowledged in scientific studies and in government documents but, except for salinity problems, are rarely mentioned by local actors.
} 


\subsubsection{Groundwater as the Enabler of a Socio-economic Transition: Who Are Left Behind?}

The different North African States, the private sector, and farmers alike acclaimed groundwater as an enabler of more productive agriculture, and a safety net for small-scale agriculture threatened by droughts. Groundwater is associated with 'modern' agriculture, improving the social status of farmers. Quarouch et al. (2014) showed that farmers look on groundwater as a means of gaining access to "unlimited horizons," where water no longer censors their existence. This can be compared with observations made in large-scale irrigation schemes, where farmers experienced access to groundwater as emancipation from State water (Kuper et al. 2009).

The recent boom in agricultural production was supported by a recent cycle of ambitious public policies aimed at agricultural productivity. The opportunities offered by the rapid development of the groundwater economy attracted many newcomers. In Morocco, the Green Morocco Plan had the clearly stated objective of facilitating access to land and water for 'modern' investors, who would be able to exploit these resources in line with new ambitions. The State granted substantial subsidies for irrigation (tube-wells, drip irrigation) and plantations to stimulate private investment by new entrepreneurs. There is even a discourse claiming that certain categories of farmers, such as the former assignees of agrarian reform cooperatives, do not "participate in the economic development of the Nation" (Papin-Stammose et al. 2013). In Algeria, the Saharan 'Eldorado' attracted many newcomers; investors who were keen to take advantage of the interesting returns of the Saharan farming systems, but also young people for whom the rapid socioeconomic promotion represented an exciting opportunity.

While the groundwater economy brought undeniable social and economic progress to some, other groups of actors were marginalized. We have shown three orders of inequality in groundwater access and use. Firstly, large numbers of farmers did not obtain access to groundwater. In the Tadla irrigation scheme (Morocco), only $50 \%$ of the farmers have access to groundwater. It is mainly small-scale farmers $(<2$ ha) who are left behind (Kuper et al. 2012). A recent study in the Cheliff irrigation scheme (Algeria) showed that only $38 \%$ of farmers had access to groundwater, while the remaining farmers were "trapped in a process of impoverishment" (Amichi et al. 2012). The second source of inequality is the pump equipment as we showed for the Saiss. Farmers with poorly equipped wells, which are running dry, have difficulty competing with those who drill deep tubewells and invest in high-value agriculture. The third source of inequality is the economic status of different categories of farmers in the skewed access and use of groundwater (ibid.). This may lead to similar social and economic differentiation to that reported in Gujarat (Prakash 2005). Social inequity may also undermine the development of local agriculture, as the majority of farmers (and their offspring) may be tempted to give up farming. Finally, the trend to increasing socio-economic inequality is a threat in the strained political context of North Africa, as most groundwater economies rely on overexploited aquifers. 
However, different, often informal, mechanisms exist to deal with unequal access to groundwater. This contradicts common perceptions, as the groundwater economy is always presented as a private affair. "A farmer, a well" farmers in Morocco replied when asked whether they would be willing to share a (tube-) well (Quarouch et al. 2014). In India, Shah (1993) showed how thriving informal water markets provide access to those that do not have their own tube-well. Shah and Bhattacharya (1992) reported another interesting mechanism - the 5-7,000 informal 'tube-well companies' in Gujarat where farmers jointly invest in deep tubewells. In North Africa, such mechanisms can also be found. In Biskra, we observed informal tube-well associations that reminded us of the Gujarati tube-well companies. More importantly, informal water markets, often intertwined with access to other production factors (land, capital, labour) ensure the integration of large numbers of small-scale farmers in the groundwater economy (Ammar Boudjellal et al. 2011). Unlike in South Asia, selling water directly and independently from a larger contractual but informal arrangement is generally (still) not done. Investigating these different mechanisms and their evolution may be an interesting way to contribute to the debate on how to deal with mounting inequalities. Finally, there are still areas where collective access to groundwater enables more generalized access to groundwater. These are mainly communitymanaged irrigation schemes and public tube-well schemes. In Tunisia, for instance, almost $30 \%$ of the groundwater-based irrigated area depend (in part) on public tube-wells. However, both types of systems appear to be declining, because of diminishing investments in collective irrigation schemes, resulting in degraded equipment, and the proliferation of private tube-wells in these schemes, as farmers want to obtain a more secure access to groundwater.

\subsubsection{The Groundwater Economy Is an Informal Economy, Should It Remain So?}

The global groundwater economy emerged in a period when rural development was no longer considered to be the sole responsibility of the State. "Less state, more market" aptly described the general opinion of how development should take place, and the State was basically asked to get out of the way of private initiative (Shah 2009). Since the initiative, investment and management of the groundwater economy is mainly a private affair, the State's "writ does not run" in such informal water economies (Shah 2009). The groundwater economy that emerged in Algeria, Morocco and Tunisia is dominated by informal arrangements for access to water, land and other resources, and by actors whose role is not formally acknowledged (Ammar Boudjellal et al. 2011). If farmers remain in the invisible world of informal groundwater economies, this may increase the risk of domination by opportunist investments, which are both socially and ecologically unsustainable (Errahj et al. 2009). On the other hand, State intervention will not necessarily lead to improved social, economic and environmental sustainability of the groundwater 
economy. Formalizing access to groundwater could cement existing inequalities, and should thus be considered with caution (Mukherji 2006).

In North Africa, groundwater is now firmly associated with productive irrigated farming. By extension, groundwater became an important part of what remained a national priority for North Africa's political economies (Allan 2007). Interestingly, our results showed that the State was an active but not always very visible actor in the groundwater economy through different (in) direct mechanisms. First, the State provided water to a substantial number of farmers through public tube-wells, although the importance of these schemes has declined. Second, the three States have made considerable efforts to provide basic infrastructure in rural areas, thus facilitating the deployment of the groundwater economy. The electrification of rural areas, for example, enabled the spread of more powerful tube-wells. Third, many authors deplored the fact that the existing regulations on groundwater use were not applied. We do not entirely agree. The "tolerant" State allowed the private sector to appropriate access to groundwater resources (Brochier-Puig 2004). However, the rules-in-use were continuously evolving in a negotiated process between the State and the private actors. In Morocco for instance, this led to an increasing number of tube-wells registered by river basin agencies. On the other hand, the volumes extracted are not regulated anywhere, thereby revealing the limits of the on-going negotiations. Fourth, the different states subsidized the groundwater economies directly (through tube-wells) and indirectly (through energy, drip irrigation, fruit trees).

We have shown, in particular, that the subsidies for micro-irrigation were an important stimulus for the groundwater economy. Fifth, experience shows that the protagonists of groundwater economies who are in peril will sooner or later call on the State to find solutions (Houdret 2012). Private actors look for public protection by claiming, for instance, to include their land in a public irrigation scheme; the State thus becomes co-responsible for finding solutions to declining water resources. This happened in the Souss (Morocco) where citrus farmers had overexploited groundwater resources, and (by calling on the State) managed to obtain access to surface water by means of a $90 \mathrm{~km}$ pipeline, thereby marginalizing a large number of small-scale farmers (Houdret 2012). This appears to contradict earlier tough talk by the administration, as documented in the 1974 Water Master Plan of the Souss: "If the private sector should continue to disregard bans on planting (orchards) or pumping, it should be prepared in the future to fully support the most disastrous consequences" (Nhrira 2011).

In sum, while at first sight the groundwater economies in North Africa appear to be based on private initiative, the presence of the State remains important through different formal and informal channels. However, there are very few examples in the region of substantial discussions between the different actors on the future of the different groundwater economies. 


\subsection{Conclusions: Privatization of Groundwater?}

Groundwater is now an important resource in North Africa - for farmers, the private sector, and the State. Over the past 30 years it has gradually become a lifeline for farmers engaged in irrigated agriculture. It saved farmers from structural droughts, and enabled them to intensify farming systems. It created many jobs in the grey support sector which developed in the wake of, and contributed to, the mounting groundwater economy. It enabled the different States to continue promoting irrigated agriculture as a national priority and a credible rural development option, for as long as the overexploited aquifers will continue to provide water.

The groundwater economy in the region emerged during a period of State disengagement following structural adjustments in the 1980s. It is tempting to define this as a transition from State-led surface irrigation development to private groundwater exploitation, amounting to a "privatization" of this resource. Groundwater access did end up in the hands of a minority of farmers, who are overexploiting the aquifers. However, we argue that there is also continuity in this transition or, in other words, that the trajectory of change is path-dependent. This explains why the State remained (and was held) legally but also morally 'responsible' for groundwater by users who had become dependent on groundwater. It intervened in many (in-) direct ways in what at first sight may appear to be private exploitation of groundwater. When private wells ran dry, the State even looked for additional water resources for the rolling groundwater economies, ignoring water demand management options.

So what conclusions can be drawn regarding the pathways of North Africa's groundwater economies, and the Janus nature of groundwater use (liberation or anarchy)? In our opinion, these pathways did not lead to 'anarchy' but rather to negotiated disorder in which the different interests of the farmers, the private sector, and the State were continuously realigned through various (in)formal channels. This disorder explains why groundwater continues to be overexploited in the shortor medium-term interest of those who use groundwater, those who provide services to the booming groundwater economies, and that of the permissive State looking for food security, social stability and economic development. At the same time, groundwater 'liberated' farmers only partially from State water. Groundwater was available for only a minority of farmers, with many inequalities. And even farmers who were able to obtain groundwater access were quickly confronted with other challenges, including harsh agricultural markets. In times of crisis, these farmers therefore often turned towards the State for support.

Finally, in a context of structural overexploitation of aquifers, crisis situations are likely to occur frequently in the next decade or so. This is not only the case in North Africa, but in many other parts of the world. Most actors depending on groundwater are well aware of these imminent crises. However, there are few examples of concerted and negotiated strategies to deal with such crises. Perhaps, the wider implications of this study relate to giving more visibility and importance to the short and medium-term effects of current dynamics and the impending decline of groundwater economies in order to create "space for change" (Leeuwis 
and Aarts 2011). This may in particular entail building coalitions of actors around the definition and analysis of scenarios of change pertaining to how the groundwater economy may evolve in the future. Research has certainly a major role to play in enabling such reflections.

Acknowledgments Research for this study was carried out in the framework of the 'Groundwater Arena' project, funded by the French National Research Agency (CEP S 11/09), and the Sirma collaborative agreement.

Open Access This chapter is distributed under the terms of the Creative Commons AttributionNoncommercial 2.5 License (http://creativecommons.org/licenses/by-nc/2.5/) which permits any noncommercial use, distribution, and reproduction in any medium, provided the original author(s) and source are credited.

The images or other third party material in this chapter are included in the work's Creative Commons license, unless indicated otherwise in the credit line; if such material is not included in the work's Creative Commons license and the respective action is not permitted by statutory regulation, users will need to obtain permission from the license holder to duplicate, adapt or reproduce the material.

\section{References}

Akesbi N (2014) Le Maghreb face aux nouveaux enjeux mondiaux. Les investissements verts dans l'agriculture au Maroc. IFRI, Paris. http://dev.ocppc.lnet.fr/sites/default/files/IFRI_ noteifriocpnakesbi.pdf

Akesbi N, Guerraoui D (1991) Enjeux agricoles: évaluation de l'expérience marocaine. Editions le Fennec, Casablanca

Al Atiri R (2007) Evolution institutionnelle et réglementaire de la gestion de l'eau en Tunisie: Vers une participation accrue des usagers de l'eau. In: Bouarfa S, Kuper M, Debbarh A (eds) L'avenir de l'agriculture irriguée en Méditerranée. Nouveaux arrangements institutionnels pour une gestion de la demande en eau. 3rd Wademed seminar. Cirad, Montpellier

Allan JAT (2007) Rural economic transitions: groundwater uses in the Middle East and its environmental consequences. In: Giordano M, Villholth KG (eds) The agricultural groundwater revolution: opportunities and threats to development, vol 3. CABI, Wallingford, UK

Alley M, Leake SA (2004) The journey from safe yield to sustainability. Ground Water 42 (1):12-16

Amichi H, Bouarfa S, Kuper M, Ducourtieux O, Imache A, Fusillier JL, Bazin G, Hartani T, Chehat F (2012) How does unequal access to groundwater contribute to marginalization of small farmers? The case of public lands in Algeria. Irrig Drain 61(S1):34-44

Amichi F, Bouarfa S, Hartani T, Lejars C, Belhamra M, Daoudi A, Amichi H, Kuper M (2013) Le maraîchage au service de la phoeniciculture pour développer de nouvelles frontières agricoles à El Ghrouss. In: Hartani T, Kuper M, Belhamra M (eds) Proceedings of the seminar on the governance of groundwater in the Maghreb. ENSA-CRSTRA-Cirad, Biskra

Ammar Boudjellal AA, Bekkar Y, Kuper M, Errahj M, Hammani A, Hartani T (2011) Analyse des arrangements informels pour l'accès à l'eau souterraine sur les périmètres irrigués de la Mitidja (Algérie) et du Tadla (Maroc). Cah Agric 20(1-2):85-91

Batchelor C, Reddy VR, Linstead C, Dhar M, Roy S, May R (2014) Do water-saving technologies improve environmental flows? J Hydrol 518:140-149 
Bekkar Y, Kuper M, Errahj M, Faysse N, Gafsi M (2009) On the difficulty of managing an invisible resource: farmers' strategies and perceptions of groundwater use, field evidence from Morocco. Irrig Drain 58(S3):252-263

Benblidia M (2011) L'efficience d'utilisation de l'eau et approche économique. Plan Bleu, Sophia Antipolis

Benmouffok B (2004) Efforts de l'Algérie en matière d'économie de l'eau et de modernisation de l'irrigation. In: Hammani A, Kuper M, Debbarh A (eds) Proceedings of the seminar on the modernisation of irrigated agriculture, Rabat, 19-22 April 2004. 1st Wademed seminar. IAV Hassan II, Rabat

Benouniche M, Kuper M, Hammani A, Boesveld H (2014) Making the user visible: analyzing irrigation practices and farmers' logic to explain actual drip irrigation performance. Irrig Sci. doi:10.1007/s00271-014-0438-0

Benziouche SE, Cheriet F (2012) Structure et contraintes de la filière dattes en Algérie. New Medit 11:49-57

Berahmani A, Faysse N, Errahj M, Gafsi M (2012) Chasing water: diverging farmers' strategies to cope with the groundwater crisis in the coastal Chaouia region in Morocco. Irrig Drain 61 (5):673-681

Berbel J, Pedraza V, Giannoccaro G (2013) The trajectory towards basin closure of a European river: Guadalquivir. Int J River Basin Manag 11(1):111-119

Bouchedja A (2012) La politique nationale de l'eau en Algérie. In: Euro-RIOB 2012, $10^{\text {ème }}$ Conférence Internationale, Istanbul, 17-19 Oct 2012

Brochier-Puig J (2004) Société locale et État face aux limites de la ressource eau (Nefzaoua, SudOuest tunisien). In: Picouët $\mathrm{M}$ et al (eds) Environnement et sociétés rurales en mutation, Approches alternatives. Éditions IRD, Paris, pp 307-321

Célérier J, Charton A (1925) Les grands travaux d'hydraulique agricole au Maroc. Annales de Géographie 34(187):76-80

Chevalier L (1950) Le plan de modernisation et d'équipement pour l'Afrique du Nord. Population $5(1): 166-170$

Côte M (2002) Des oasis aux zones de mise en valeur: l'étonnant renouveau de l'agriculture saharienne. Méditerranée 99(3-4):5-14

Daoudi A, Wampfler B (2010) Le financement informel dans l'agriculture algérienne: les principales pratiques et leurs déterminants. Cah Agric 19:243-248

El Alaoui M (2006) Développement de l'agriculture irriguée, dispositif juridique et institutionnel et stratégie de gestion de l'eau au Maroc. In: Bouarfa S, Kuper M, Debbarh A (eds) L'avenir de l'agriculture irriguée en Méditerranée. Nouveaux arrangements institutionnels pour une gestion de la demande en eau. 3rd Wademed seminar. Cirad, Montpellier

El Gueddari A (2004) Economie d'eau en irrigation au Maroc: Acquis et perspectives d'avenir. Hommes, Terre et Eaux 130:4-7

Errahj M, Kuper M, Faysse N, Djebbara M (2009) Finding a way to legality, local coordination modes and public policies in large-scale irrigation schemes in Algeria and Morocco. Irrig Drain 58(S3):358-369

Faysse N, Hartani T, Frija A, Tazekrit I, Zairi C, Challouf A (2011) Agricultural use of groundwater and management initiatives in the Maghreb: challenges and opportunities for sustainable aquifer exploitation. AfDB Econ Brief 1-24. http://www.afdb.org/en/documents/document/ economic-brief-agricultural-use-of-groundwater-and-management-initiatives-in-the-maghrebchallenges-and-opportunities-for-sustainable-aquifer-exploitation-25496/

Faysse N, El Amrani M, El Aydi S, Lahlou A (2012) Formulation and implementation of policies to deal with groundwater overuse in Morocco: which supporting coalitions? Irrig Drain 61(S1):126-134

Hammani A, Hartani T, Kuper M, Imache A (2009) Paving the way for groundwater management: transforming information for crafting management rules. Irrig Drain 58(S3):240-251

Houdret A (2012) The water connection: irrigation and politics in southern Morocco. Water Altern 5(2):284-303 
Imache A, Hartani T, Bouarfa S, Kuper M (2010) La Mitidja, 20 ans après: réalités agricoles aux portes d'Alger. Editions Alpha, Algiers

Jus H (1878) Les forages artésiens de la province de Constantine: résumé des travaux éxécutés de 1856 à 1878. Impr. Nouv., Paris

Khiari A (2002) Une région pionnière dans le Sahara algérien: El Ghrouss. Méditerranée 99 $(3-4): 27-30$

Konikow LF, Kendy E (2005) Groundwater depletion: a global problem. Hydrogeol J 13 (1):317-320

Kuper M, Hammani A, Zemzam S, Bouarfa S, Thomas V (2003) Stratégies d'utilisation conjuguée des eaux de surface et souterraine pour l'irrigation: le cas du périmètre irrigué du Tadla au Maroc. In: Proceedings of the 3rd Pcsi seminar on the Integrated water management in river basins. Cirad, Montpellier

Kuper M, Dionnet M, Hammani A, Bekkar Y, Garin P, Bluemling B (2009) Supporting the shift from "state" water to "community" water: lessons from a social learning approach to design joint irrigation projects in Morocco. Ecol Soc 14(1):19

Kuper M, Hammani A, Chohin A, Garin P, Saaf M (2012) When groundwater takes over: linking 40 years of agricultural and groundwater dynamics in a large-scale irrigation scheme in Morocco. Irrig Drain 61(S1):45-53

Leduc C, Ben Ammar S, Favreau G, Béji R, Virrion R, Lacombe G, Tarhouni J, Aouadi C, Zénati Chelli B, Jebnoun N, Oï M, Michelot JL, Zouari K (2007) Impacts of hydrological changes in the Mediterranean zone: environmental modifications and rural development in the Merguellil catchment, central Tunisia. Hydrol Sci J 52(6):1162-1178

Leeuwis C, Aarts N (2011) Rethinking communication in innovation processes: creating space for change in complex systems. J Agric Educ Ext 17(1):21-36

Lightfoot DR (1996) Moroccan Khettara: traditional irrigation and progressive desiccation. Geoforum 21(2):261-273

Llamas MR (1998) Groundwater overexploitation. In: Proceedings of the UNESCO-IHP conference on world water resources at the beginning of the 21 st century, Paris

Llamas MR, Martínez-Santos P (2005) Intensive groundwater use: silent revolution and potential source of social conflicts. J Water Resour Plan Manag 131(5):337-341

Lopez-Gunn E, Llamas MR (2008) Re-thinking water scarcity: can science and technology solve the global water crisis? Nat Res Forum 32(3):228-238

MacDonald AM, Bonsor HC, Dochartaigh BEO, Taylor RG (2012) Quantitative maps of groundwater resources in Africa. Environ Res Lett 7(2):024009

Mamou A, Kassah A (2002) Eau et développement dans le Sud tunisien: projet national mobilisateur 'potentialités et gestion de l'eau dans le Sud tunisien'. CERES, Tunis

Margat J (2008) Exploitations et utilisations des eaux souterraines dans le monde, vol 52. Unesco/ BRGM, Paris

Margat J, Vallée D (1999) Vision méditerranéenne sur l'eau, la population et l'environnement au XXIème siècle. Plan Bleu, Sophia Antipolis

Mekki I, Jacob F, Marlet S, Ghazouani W (2013) Management of groundwater resources in relation to oasis sustainability: the case of the Nefzawa region in Tunisia. J Environ Manage 121:142-151

Mitchell M, Curtis A, Sharp E, Mendham E (2012) Directions for social research to underpin improved groundwater management. J Hydrol 448-449:223-231

Moench M (2007) When the well runs dry but livelihood continues: adaptive responses to groundwater depletion and strategies for mitigating the associated impacts. In: Giordano M, Villholth KG (eds) The agricultural groundwater revolution: opportunities and threats to development. CABI Head Office, Oxford, pp 173-192

Monition L, de Lesguise MN (1954) Contribution à l'étude du drainage naturel des nappes aquifères. In: Proceedings Ass. Int. Hydrol. Sa., CR Assembl. Gén., Rome, pp 499-519

Mukherji A (2006) Political ecology of groundwater: the contrasting case of water-abundant West Bengal and water-scarce Gujarat, India. Hydrogeol J 14:392-406

Nhrira A (2011) La sauvegarde des eaux souterraines dans le Bassin du Souss Massa. In: Proceedings of the groundwater conference, 14-16 March 2011. Afeid, Orléans 
Otmane T, Kouzmine Y (2013) Bilan spatialisé de la mise en valeur agricole au Sahara algérien Mythes, réalisations et impacts dans le Touat-Gourara-Tidikelt. Cybergeo: European Journal of Geography, Espace, Société, Territoire 632

Papin-Stammose C, Petit O, Kuper M (2013) Résilience des paysanneries marocaines dans un contexte de mutations de l'accès aux ressources productives: cas du Saiss. In: Hartani T, Kuper M, Belhamra M (eds) Proceedings of the seminar on the governance of groundwater in the Maghreb. ENSA-CRSTRA-Cirad, Biskra

Pascon P (1978) De l'eau du ciel à l'eau de l'état: psychosociologie de l'irrigation. Hommes, Terre et Eaux 8(28):3-10

Penov I (2004) The use of irrigation water in Bulgaria's Plovdiv region during transition. Environ Manage 34(2):304-313

Poncet J, Kuper M, Chiche J (2010) Wandering off the paths of planned innovation: the role of formal and informal intermediaries in a large scale irrigation scheme in Morocco. Agr Syst 103 (4):171-179

Popp H (1986) L'agriculture irriguée dans la vallée du Souss. Formes et conflits d'utilisation de l'eau. Méditerranée 59(4):33-47

Postel S (1999) Pillar of sand: can the irrigation miracle last? WW Norton, New York

Prakash A (2005) The dark zone: groundwater irrigation, politics and social power in North Gujarat. PhD thesis, Wageningen University and Research Centre

Quarouch H, Kuper M, Abdelaoui E, Bouarfa S (2014) Eaux souterraines, sources de dignité et ressources sociales. Cas d'agriculteurs dans la plaine du Saïss au Maroc. Cahiers Agricultures. doi:10.1684/agr.2014.0699

Riaux J (2013) Engager la construction d'un regard sociohydrologique: des archives catalyseurs de l'interdisciplinarité. Nat Sci Soc 21(1):15-23

Rojas R, Kahunde S, Peeters L, Batelaan O, Feyen L, Dassargues A (2010) Application of a multimodel approach to account for conceptual model and scenario uncertainties in groundwater modelling. J Hydrol 394(3):416-435

Shah T (1993) Water markets and irrigation development: political economy and practical policy. Oxford University Press, Bombay

Shah T (2009) Taming the anarchy: groundwater governance in South Asia. Resources for the Future Press, Washington, DC

Shah T, Bhattacharya S (1992) Farmer organisation for lift irrigation: irrigation companies and tubewell co-operatives of Gujarat. In: Singh K, Ballabh V (eds) Symposium on management of rural co-operatives. Institute of Rural Management, Anand

Shah T, Deb Roy A, Qureshi AS, Wang J (2003) Sustaining Asia's groundwater boom: an overview of issues and evidence. Nat Res Forum 27(2):130-141

Siebert S, Burke J, Faures JM, Frenken K, Hoogeveen J, Doll P, Portmann FT (2010) Groundwater use for irrigation - a global inventory. Hydrol Earth Syst Sci 14:1863-1880

Swearingen WD (1987) Moroccan mirages: agrarian dreams and deceptions, 1912-1986. IB Tauris Publishers, London/New York

Trabelsi R, Zaïri M, Smida H, Ben Dhia H (2005) Salinisation des nappes côtières: cas de la nappe nord du Sahel de Sfax, Tunisie. Comptes Rendus Geosci 337(5):515-524

Venot JP, Zwarteveen M, Kuper M, Boesveld H, Bossenbroek L, Van Der Kooij S, Wanvoeke J, Benouniche M, Errahj M, De Fraiture C, Verma S (2014) Beyond the promises of technology: a review of the discourses and actors who make drip irrigation. Irrig Drain 63(2):186-194

Ziyad A (2007) Renouvellement de la politique de l'eau au Maroc: quel apport du débat national sur l'eau? Hommes Terre Eaux 137:59-61

\section{Official Data}

Agences de Bassin Hydraulique (ABH) (2011) Plan directeur d'aménagement intégré des ressources en eau (PDAIRE), Rabat, Morocco 
Direction Générale des Ressources en Eau (DGRE) (2005) Situation de l'exploitation des nappes phréatiques. Tunis, Tunisia

Direction Générale des Ressources en Eau (DGRE) (2008) Annuaire de l'exploitation des nappes profondes. Tunis, Tunisia

Direction Générale du Génie Rural et de l'hydraulique agricole (DGGREE) (2006) Computer data base, accessed on 23/9/2013. Tunis, Tunisia

High Planning Commission (HCP) (2007) Prospective Maroc 2030: Quelle agriculture pour le Maroc? Rabat, Morocco

Ministère de l'Agriculture et de la Pêche Maritime (MAPM) (2012) Situation de l'agriculture marocaine. Rabat, Morocco

Ministère des Ressources en Eau (MRE) (2009) Etude d'inventaire et de développement de la PMH. Algiers, Algeria

Ministère des Ressources en Eau (MRE) (2011) Note sur l'activité de l'hydraulique agricole. Algiers, Algeria

TICET (2009) Institutional framework and decision making practices for water management in Tunisia. Project report of the CITET. Tunis, Tunisia 